\title{
АЖ БОГДЫН НУРУУНЫ ФИЗИК ГАЗАРЗУЙН ТОДОРХОЙЛОЛТ
}

\author{
Э.Авирмэд ${ }^{I}$, Б.Баянжаргал ${ }^{l}$ \\ ${ }^{1}$ ШУА-ийн Газарзүй-Геоэкологийн хүрээлэн, Монгол улс \\ Цахим шуудан: avirmed_cave@yahoo.com, bayanaa_geo@yahoo.com
}

\section{ОРШИЛ}

Монгол Алтайн нурууг бүрэлдүүлж байгаа томоохон салбар уулсын нэг болох Аж Богдын нурууны физик газарзүйн тодорхойлолт байдаггүй юм. Аж Богдын нуруу нь Монгол Алтайн уулт тогтолцооны урагшаа нумарсан хэсэгт энэ уулт тогтолцооноос урагшаа салж салбарлаж гол нуруунаасаа дөрөлж даваагаар холбогдон уулс хоорондын хөндий, хотгороор хүрээлэн тогтсон уулт тогтолцоо юм. Аж Богдын нуруу нь ихэнхдээ эрт дунд хожуу үеийн настай карбоны эриний болон дээд дунд девоны галавын хурдаснаас бүрэлдэн тогтсон эгц цавчим хажуутай, бөмбөгөр оройтой, хэрчигдсэн, хурдас чулуулгийнхаа онцлогтой холбоотой давчуу гүн голын хөндийгөөр огтлогдсон байдаг юм. Аж Богдын нуруу нь хурдас чулуулаг, гадаргын хэв шинж, хэлбэр, элэгдэл хуримтлалын хэлбэрүүд, уулсын хажуу, хэрчигдэл, нас, ландшафтын хувьд Монгол Алтайн уулстай адилхан юм. Аж Богдын нуруу нь 931800 га талбайг эзлэн орших ба нийт хилийнх нь урт 446 км урт юм.
Аж Богдын нурууны тухай судлаачид өөр өөрсдийн хийсэн судалгааны дүгнэлтийг үлдээсэн байдаг юм. 1952 онд нэрт газарзүйч, судлаач Э.М.Мурзаевын Монгольская Народная Республика / Физико-географические описание/ номын Алтайн өмнөх ба Зүүн гарын говь гэсэн хэсэгт энэхүу нутгийг хойд ба өмнөт талаас нь хүрээлэн орших Алтай ба Тяньшаны өндөр их уулс байгаа явдал нь Алтайн өмнөх говийн нэг чигийн биш харин өргөрөгийн дагуу ба зүүн урьд зүг рүҮ чиглэн сунасан олон тооны завсрын уулсыг тогтоожээ. Энд тал буюу толгод газрууд байдгийн сацуу, хэдэн арван км уул нилээд элбэг байна. Алтайн өмнөх уулс хүчтэйгээр цөлжиж нүцгэрсэн ба хуурай хавцлуудаар эрс зүсэгдсэн байна. БНМАУ-ын нутаг дах Алтайн өмнөх говийн төв хэсэг рүҮ үлдэгдэл толгод, тус тусад орших уулнууд ба урт сайрууд элбэгшиж Аж Богдоос эхлэн түр урсгалууд урсах чиг болох тус улсын өмнөт хил хүртэл бүх нутгийг бүрхэн оршино.... гэжээ.

Түлхүур үгс: Уулт тогтолщоо, гол нуруу, гадаргын хэв иинж, хэлбэр, хажуу, бэл, хөндий, уулс хоорондын хөндий, мөстөл; 


\section{МАТЕРИАЛ, АРГА ЗУЙ}

2011 онд Хар Азаргын нурууг улсын тусгай хамгаалалтанд авах судалгааны ажлын далимд Аж Богдын нуруунд геоморфологийн судалгаа, бичиглэл, хэмжилт хийж энэ нурууны товч тодорхойлолтыг хийсэн юм. Гадаргын хэв шинж, гадаргын үүсэл, хөгжил, геоморфологийн анализ, хотгор гүдгэрийн морфогенетик хэв шинж, гадаргын хэлбэр, гадаргын хэрчигдлийн шигүу, гадаргын налуу, хурдасны зузаан, фаци, хурдас чулуулгийн өнгө бүтэц, палеогеоморфологийн анализ, эдэгдлийн хэлбэрүүд, ус зүйн сүлжээ, голын хөндий, дэнжийн судалгааг хийж, 1:100 000-ны масштабтай байрзүйн зураг, SRTM-ийн өндрийн мэдээ болон Landsat хиймэл дагуулын сансрын зургийг ашиглан гадаргын налуу, өндөршлийн зургийг зохиож, гүний хагарлын шугам, гадаргын хэлбэрүүдийг сансрын зураг ашиглан сансрын зураг дээр тодруулалт хийх, харьцуулах аргаар судалгааг хийсэн болно.



Зураг 1: Аж богдын нуруу

Академич Ш.Цэгмид Монгол Алтайн нурууд зүүн өмнө чиглэлийг яг дагаж тогтсоноор барахгүй салбарууд нь ч гэсэн мөн ойролцоо чиглэлтэй юм. Орой, хярын хавтгай гадарга заримдаа их хэмжээний талбай эзэлж түүн дээр өндөр сүрлэг шовх оргил тод сүндэрлэж харагдана. Тийм өргөн гадарга яг тэгш талын байдалтай биш, ялихгүй гүдгэр гүвээнүүдтэй байдгийг үзэхэд дээш өргөгдсөн эртний тэгшрэлийн гадарга мөн гэдэг нь илэрхий. Энэ гадарга геологийн тооллоор хожуу үед өргөгдсөн болохоор усанд сайн идэгдэж амжаагүй, харин хажуунууд нь хүчтэй идэгдэж эгц болжээ. Эндэхийн нурууд дөрөвдөгч галавын үед ихээхэн мөсдөж байсны ор мөр ялангуяа хамгийн өндөр баруун хагаст тун элбэг байна. Гол нурууны зүүн хагас салбар уул харьцангуй олонтой юм. Хамгийн том нь зүүн урагшаа салбарласан Хөвчийн нуруу, Аж Богдын нуруу хоёр болно. Тэр нь шилжин Алтайн өмнөх говь руу гүн түрж орно. Аж Богдын нуруу хэм тэгш биш огшоосон тул урд зах нь илүҮ өргөгдөж өндөр оргилууд чухамхүҮ тэнд л оршино. Жишээ нь: ноён оргил Их-Овоо уул 3802 м, Мөнх Цаст уул 3671 м өндөр болно. Тэдгээрийн хэлбэр бөмбөгөрдүү ба хад цохио багатай юм. Энэ нуруу нэгэнт хэм тэгш биш болохоор урд хажуу нь эгц, хойт хажуу нь налуу бөгөөд тэнд хэд хэдэн зэрэгцээ шил оршино [2].

...Монгол Алтайн нурууны өмнө талын томоохон салбар уулсын тоонд Аж Богд, Эдрэнгийн нуруу хамрах ба эдгээрийн хамгийн үнэмлэхүй өндрийн нэгдэх нь Мөнх Цаст уул 3761м, хоёрдох нь 2042м хүрдэг. Ихэнх намхан цуварсан болон салбар уулс тэрчлэн гол нурууны өмнөт тал болон тэдгээрийн өмнөт хажуу нь гүнзгий хавцал, сайраар эрчимтэй хэрчигдсэн хадархаг эрс налуу гадаргын хэлбэрүүдтэй юм[9].

Аж Богдын нуруу нь уул зүйн байршлын хувьд Монгол Алтайн уулт тогтолцооны салбар нуруу юм. Мөн энэ нуруунаас салбарласан уул нуруу байхгүй. 
Аж Богдын нуруу нь Монгол Алтайн нурууны салбар болохооороо зүүн өмнө чиглэлийг яг дагаж тогтсоноор барахгүй гол нуруутайгаа ойролцоо чиглэлтэй юм. Уулсын орой хяр голдуу хавтгай, хажуунууд нь нилээн эгц буюу өөрөөр хэлбэл ерөнхийдөө эртний тэгшрэлийн гадарга геологийн хожуу үед өргөгдсөн байдалтай ажээ.



Зураг 2: Аж богдын нурууны сансарын зураг

Тэгээд ч Аж Богдын нуруу нь хурдас чулуулаг, гадаргын хэв шинж, хэлбэр, элементүүд, элэгдэл хуримтлалын хэлбэрүүд, уулсын хажуу, хэрчигдэл, нас, ландшафтын хувьд Монгол Алтайн нурууны өндөр уулстай адилхан юм.

\section{ҮР ДУН}

Уулзүйн байрлал: Аж Богдын нуруу нь Монгол Алтайн уулт тогтолцооны дунд хэсгийн баруун захаар орших ба Монгол Алтайн гол нуруунаас өмнө тийшээ салбарласан 3 нурууны дунд талын салбар нуруу юм. Монгол Алтайн нуруунаас хойд талаараа Зөөлөн Богдын даваа, Алаг нуурын хотгороор, баруун талаараа Их Таянгийн нуруу, Төхөмийн хоолойгоор баруун болон өмнө талаараа Хонь усны говь, Номингийн говиор зааглагдана. Алтайн уулт тогтолцоонд багтддаг Аж Богдын нуруу нь уулзүйн тогтолцоогоороо Монгол Алтайн салбар нуруунд хамаарагдана.
Аж Богдын нурууг В.М.Синицын (1959) Монгол Алтайн нурууг Алаг нуурын хотгор хүртэл үргэлжилнэ гэж Говийн Алтайд оруулсан ба Э.М. Мурзаев(1952) Монгол Алтайн нурууны төгсгөлийг Гичгэний нуруугаар авч Монгол Алтайн нуруунд оруулжээ. Ш.Цэгмид (1969) Гичгэний нурууг Монгол Алтайн төгсгөл гэж Монгол Алтайн нуруунд багтаасан бол С.Жигж (1975) геоморфологийн мужлалтандаа

Монгол Алтайн гол нуруунд багтаасан байдаг юм. Эндэхийн уулс тектоник бүтцээрээ дунд төрмөлийн настай Алтайн уулт тогтолцоонд хамрана. 




Зураг 3: Аж богдын нурууны гадаргын өндөршлийн зураг

Алтайн гол нуруутай адил баруун хойноос зүүн урагш сунаж орших ба ихээхэн элэгдэж хэрчигдсэний дээр хормойн хурдас нэн түгээмэл бөгөөд гуу жалга, хуурай сайраар хэрчигдэж бартаа ихтэй болжээ[3].

Аж Богдын нуруу нь Монгол Алтайн гол нурууны нэгэн адил баруун хойноосоо зүүн урагш 87.0 км сунан тогтсон уулс юм.

Тус нурууны баруун хойд захын цэг нь х.ө 44o56' 08,42", з.у 94о 35'06,03”- д орших Зөөлөн Богдын даваа (1725м), өмнөт захын цэг нь х.ө 44о35' 17,08”, з.у 95о 47' 04,02”, д орших Их Сонин уул (2155м), зүүн захын цэг нь х.ө 44о53' 39,20", з.у 95о 48' 59,57”, -д орших Талын Уушиг уул (1582м), баруун захын цэг нь х.ө 45o10' 57,55”, з.у 94o 57'01.23" -д орших Өртөөн Худагийн хяр (1809.2м) юм. Аж Богдын нуруу нь Номингийн говийн хотгорын баруун талын усан хагалбар болно. 2500-3700 м өндөр оройтой эгц хажуу бүхий өндөр уулс, тэдгээрээс эх аван урсах голуудын хөндий хосолсон томоохон нуруу юм. Далайн түвшнээс дээш дундажаар 2900 м өндөр өргөгдсөн баруун хойноос зүүн урагш сунаж тогтсон хамгийн өргөн газраa 83.0 км, нарийн газраа 31.3 км өргөнтэй юм.

Тус нурууны хамгийн өндөр ноён оргил нь Их овоо уул (3802.3м), өндөрт сүндэрлэнэ. Аж Богдын нуруунд 3000м-ээс дээш өндөртэй Тэрэгтийн нуруу (3757.3м), Их Ойм (3566.0м), Бага Ойм (3474.2м), Загалын Овоо (3463.1м), Бунхан уул $(3460.7 \mathrm{M})$, Алтанхайрхан $(3387,4 \mathrm{M})$, Баянцагаан $(3386,0 \mathrm{M})$, Хүрэн тэвх (3081.6м), 2500м-ээс дээш өндөртэй Зараа уул(2705,7м), Лха хайрхан (2700,3м), Бунгийн Улаан (2823.2м), Халба Хайрхан (2619.5м), Ламын худгийн ухаа (2876.9м), Айчгуч Богд (2747.4м), Зөөлөн Богд (2545.5м) уул сүндэрлэнэ.

Геологийн тогтоц: Аж Богдын нуруу нь палеозойн эриний дивон, карбон дээд, дунд галавын хурдаснаас тогтсон бөгөөд тус нурууны зүүн, зүүн өмнөт хэсэг нь бүхэлдээ палеозойн эриний карбон галавын эхэн, дунд болон хожуу үеийн (C2-3), хүчиллэг, шүлтлэг кварц, диорит, грансеонит, боржин девоны түрүү үеийн настай (D1ul), хүрэм, андези хүрэм тэдгээрийн бөсөл элсжин, бөсөл гравилить, цахиуржин, хас, баруун хэсэг нь дээд девон-доод корбоны (D3-C1), 
үеийн настай элсжин, алеворлит, шаварлаг занар, хайргажин, шохойжин, хүрмэн, андезит, дунд хүчиллэг-холимог найрлагт бөсөл, хас маягийн хурдаснаас тогтсон байна [4]. ... Дөрөвдөгч галавын эхээр Альпийн уул тогтох хөдөлгөөн үргэлжилж хотгор гүдгэр өөрчлөгдөн байгуулагдах үйл явц болсоор байв. Энэ тектоник хөдөлгөөн нийтдээ эрч ихтэй боловч тус орны нутаг бүрд жигд хүчтэй явагдсангүй. Түүний хүч баруун болон хойд зүгийн нутагт нэн их байсан тул хуучин уулт нутгийг өндөрт өргөснөөр Алтай, Хангай, Хэнтийн нуруу одооныхоо байдлын олж авчээ. [1]

Аж Богдын нурууны баруун биеэр дайран гарсан уулын дагуу чиглэлтэй эртний томоохон хэдэн тектоник хагарлуудын ул мөр хадаглагдаж үлджээ. Эдгээрээс хамгийн урт нь Хөвчийн нуруу, Аж Богдын нурууг зааглах Их шар хөтөл буюу Зөөлөн Богдын даваанаас эхэлж 161,3км үргэлжилэх тууш хагарал юм. Энэ хагарал Аж Богдын нурууны баруун өврийг зааглаж байдаг юм.

Хоёрдох хагарал нь уг нурууны дагуу чиглэлтэй тууш хагарал нь Зөөлөн Богдын нурууг дундуур нь хуваасан 18,4 км урт хагарал юм. Мөн энэ нуруунд баруун өмнөөсөө зүүн хойш чиглэсэн хоорондоо нилээд зайтай 3 зэрэгцээ хагарал бий. Эдгээр хагарлуудыг даган тогтсон уулс хоорондын хөндий үүссэн бий. Эдгээр хагарлуудаар хязгаарлагдсан гүний чулуу оргилон гарч царцан тогтсон 3 хэсэг цагираг хэлбэртэй өргөгдөл үүсчээ. Энэ нурууны зүүн өмнөт төгсгөл хэсэгт томоохон хэмжээтэй цагираган бүтэц тавцан байдлаар үүссэн нь тод ажиглагддаг юм. Аж Богдын нуруунд сүүлийн үеийн хагарал гадаргад ажиглагдахгүй байна.

Аж Богдын нуруу нь маш гүн хэрчигдсэн, уулсын хажуу маш их налуу, заримдаа бараг эгц хажууг үүсгэсэн байна. Ихэнх төлөв хавцал үүсгэсэн бий. Ерөнхийдөө нарийн хавцлын хэсэг нь үндсэн чулуулаг гадарга дээр гарсан зурвастай холбоотой байна. Зарим нэг хавцал нь гол нурууныхаа ноён оргилуудаас эхэлсэн байна. Хажуу эрс, хадархаг 25 градусаас их хэвгийтэй. Харин энд усны элэгдэл, физик өгөршил нэн эрчимтэй явагдсан. Түр зуурын урсгал усны үйлчлэлээр сайр олноор үүсч зарим газар шигүү оршдог улмаас уулын хажуу бэлийг сархиаг болгожээ. Аж Богдын нурууны зүүн бэлийн урт 25-30 км үргэлжилсэн байхад баруун талын бэл нь 35,3 км урт бэл ҮҮссэн бий.

Аж Богдын нуруу говь цөлийн нөлөөнд ихээхэн орж элэгдэж эвдэрсэн болохоор уулсын орой нь шовх, хад чулуутай, хажуунууд нь ихэвчлэн эгц, хад асга ихтэй болж хувирсаны зэрэгцээ урсгал ус ховроос тэрхүу элэгдэл эвдрэлийн материал хол зөөвөрлөгдөх боломж бага тул уулсын хажууд хуримтлагдсанаар асар урт бэлийг бий болгожээ. Монголын бэлийн тухай бэлийн геологи, морфологи, түүний гарал үүсэл, морфоструктурын шинж чанарыг Монгол Алтайн уул үүсэх хөдөлгөөнтэй холбон бичсэн байна [6].

Бэлийн хэвгий талын гадарга уулнаас урсах маш олон тооны гол, горхи, ганга, жалгаар хэрчигдсэн байна. Бэлүүдийн налуу уулнаас холдох тусам багасдаг. Бэл бол элэгдлийн тэгшрэл идэвхтэй явагдаж байгаа орчин үеийн рельефийн хэлбэр юм. Түр зуурын урсгалтай хуурай сайр хөндийгөөр хэрчигдсэн бүс юм. Дээд хэсэгтээ элэгдлийн шигүү, гүн маш их байхад доод хэсэгтээ шигүу, гүн багасч ухрах элэгдэл их байна. Бэлийн дээд хэсгийг хайрган, доод хэсгийг шаварлаг давхрагатай гэж ялгаж болох юм. Түр зуурын урсгалтай сайр дээд бүсэд шигүу юм. Бэлийн дээд бүс нь нилээд налуу 6-100, 12-130 градус налуутай байна. Томоохон хуурай сайрын өргөн 100-300 м гүн нь 2-4 м байна. Ёроол нь тэгш, бул чулуу дэвсэгдсэн, муу ангилагдсан хайрга бүхий ихэнхдээ овон товонтой. Сайрын эрэг нь эгц байна. Эрэг нь пролювийн томоохон ширхэгтэй хэвтээ үелсэн зузаан үе давхаргаас бүрдсэн байна. Аж Богдын нурууны баруун хойд талын бэлд Зөөлөн сүүж (1570.0), Өртөөн худгийн хар (1809.2) 
зүүн хойд бэлд Хойд талын хар (1860.6м), Урд талын хар (1970.1м) Талын уушиг уул (1582.9м) зэрэг үлдэгәл уулс үүсэж тогтсон байхад уг нурууны баруун бэл, өмнөд хэсгийн бэлийн зарим хэсэгт аараг толгод бий.

Геоморфологийн товч: Аж Богдын нуруу нь Монгол орны геоморфологийн мужлалтын хувьд Алтайн өвөр говийн нам уулс, цав толгод, тал газрын их мужийн Говь маягийн бэсрэг болон нам уулсын мужид багтана[3]. Аж Богдын район тектоник бүтцээр өмнөт монголын тогтолцоонд орох бөгөөд Алтайн цаадах говийн нилээд томхон тарамцаг юм. Аж богдын эргэн тойронд хэдэн арван километр газарт хормойн хурдаст тал үргэлжлэхийн зэрэгцээ бэлийн хурдас уулсыг гартал бүрхэхийн хамт гадарга нь түр урсгалтай хуурай сайраар нэн их хэрчигдэж огтроожжээ[3].

Уулсын тогтолцооны ерөнхий дүр төрх нь баруун хойноосоо зүүн урагш сунаж тогтсон хэлбэртэй нэг цулдам уулс, голын хөндийнүүдээр хэрчигдсэн байдалтай юм. Аж Богдын нуруу нь өргөгдөл, элэгдэл эвдрэлтэй холбоотой уулын хяр нь бөмбөгөр, хажуу нь налуу ихтэй, олон нарийн жалгаар огтлогдсон байдаг юм. Аж Богдын нуруу хотгор гүдгэрийн гадаад төрх байдал нь геологийн урт удаан хугацааны туршид элэгдэл, усны идэгдлийн үйл явцад автсаны улмаас уулсын орой ихэвчлэн шовх хадан хана, асга нурагаас тогтсон байна.

Энэ нуруу нь каледоны атриат бүсэд хамрах бөгөөд дунд болоод шинэ төрмөлийн эриний сүүл үеийн шинэхэн тектоник хөдөлгөөнд хүчтэй автагдан, гадаргын байдал нь альпийн хэв шинжит уулсын төрхийг олжээ.

Хотгор гүдгэрийн морфогенетик хэв шинж: Аж Богдын нуруу нь тектоник хөдөлгөөнөөр үүсч өндөрт өргөгдсөн болон царцдасын гадаад хүчний элэгдлээр засварлагдан өөрчлөгдөж байгаа тектоникэлэгдлийн хэв шинжит хотгор гүдгэр бүхий уулт тогтолцоонд орно. Энэ нурууны гадаргад тектоник-элэгдлийн хэв шинжит хотгор гүдгэр зонхилох байрыг эзэлнэ. Шинэхэн тектоник хөдөлгөөнд хүчтэй автаж өндөр болсон уул юм. ...Эдгээр уулс каледонитийн хожуу үеийн атриат тогтолцоо бүхий суурь дээр шинэхэн тектоник хөдөлгөөн, тус орны бусад нутгаас илүY эрчимтэй болсны нөлөөгөөр буюу царцдасын дотоод хүчний үйл ажиллагаа, гадаад хүчний үйл ажиллагаанаас хавьгүй хүчтэй байсны улмаас өндөрт өргөгдсөний зэрэгцээ дөрөвдөгч галавын туршид 1-3 удаа мөсдөж, ерөнхийдээ эгц хажуутай, шовх оройтой ян сарьдаг голлосон өндөр уулс юм[3].

Аж Богдын нурууг 1969 онд боловсруулсан Монгол орны физик газарзүйн мужлалтаар [2] Алтайн уулархаг их мужийн Монгол Алтайн мужийн Алтайн зүүн хэсэг Б тойрогт багтаасан бол Монгол оны физик газарзүйн шинэчилсэн мужлалаар /1999/ төв Азийн заримдаг цөл, цөлийн их мужийн Алтайн өвөр говийн мужийн Алтайн өвөр говийн баруун хэсгийн хэт гандуу цөлийн дэд мужид [4] хамааруулсан байна.

Аж Богдын нурууны голуудын эх авсан 3100м өндөр өргөгдсөн 300 нуруудад томоохон талбайтай эртний тэгширлийн гадарга бий. Энэ тэгш хавгайн хонхор хотост Загалын нуур, Оймын нуур, Хар нуур зэрэг хярын нуурууд үүссэн нь бий.

Аж Богдын нуруу нэгэн хэвийн тавцан хэлбэрийн хяртай, нуруудын дээд хэсэг нь ихээхэн тэгширсэн, эгц налуу хажуу бүхий гадаргын хэлбэртэй. Уулсын оройгоор сэрвэн хад цохио мэр сэр тохиолдоно. Уусын хажуу эгц цавчим, элэгдэл эвдрэлээр үүссэн асга нураг ихтэй. Уулын хажууд үүссэн ийм хурдас нь байнга нэмэгдэж шилжиж байх ба уулын дээд хэсгээр асганы ширхэг бага байхад уулын хормой орчимдоо нургийн хурдасны хэмжээ томорч налуу багассантай холбоотой хөдөлгөөн нь багасна. Уулын оройн хад чулуу халуун хүйтний элэгдэл эвдрэлээс болж хагарч бутран доош бууж 
голын хөндийд том том бул чулуу овоорсон нь бий. Дулааны улиралд цас борооны үед хад нурж асга нураг ихээр үүснэ. Асга нураг үүсээгүй уулын ар, энгэр бараг байхгүй. Дан ганц асга чулуунаас тогтдог, хамт үүссэн хөрс шороо нь усаар угаагдан зөөгдөж, үргэлж шилжиж байдаг болохоор хөрс үүсч ургамал ургах нөхцөл байхгүй юм.

Энэ нурууны баруун хэсэгт баруун хойноосоо зүүн урагш нарийхан сунаж тогтсон Дээд девон-доод карбоны настай шохойн чулуун зурвас үе гадаргад ихээр гарч ирж шохойн чулуунаас тогтсон уул нурууг Үүсгэжээ.

Орчин үеийн нэг чухал хүчин зүйл бол хүйтний өгөршил уулын чулуулгийн хуримтлал, асгарга үүссэн байхад урсгал усны үйл ажиллагаагаар өргөн бэлүүд хушуу туудас үүсгэн ихээхэн бартаажсан байна.

Гадаргын хэвгий: Аж Богдын нуруу далайн түвшнээс дээш 2000-3800м м хүртэл өндөр өргөгдсөн, уул нурууд нь тэгшивтэр, бөмбөгөр оройтой орой хяртай, хажуунууд нь нилээд гүн хэрчигдсэн, үлдэгдэл хад цохио элбэгтэй, техтоник гаралтай ан цавыг дагаж тогтсон гүн нарийн хавцал, хөндийгөөр ихээхэн хэрчигдсэн байна. Энэ нуруун ас мы оргилууд нь 3000 метрээс дээш сүндэрлэх ба эгц хажуу гол төлөв хад асга, нураг чулуунаас тогтоно.

$0^{\circ}-3^{\circ}$-ийн налуу гадарга Аж Богдын нурууны 55,7\% буюу 518950 га талбайг эзэлнэ. Ийм налуутай гадаргад 1600м-ээс доош өндөртэй уулсын хоорондох хөндий хоолойнууд, тал газар орно.

$3^{\circ}-6^{\circ}$-ийн налуу гадарга Аж Богдын нурууны $18,6 \%$ буюу 173130 га талбайг эзэлнэ. Ийм налуутай гадаргад 1600-2600м өндөртэй хуурай сайруудаар хэрчигдсэн уулын бэл, хормой, орно.

$6^{\circ}$ - $9^{\circ}$-ийн налуутай гадарга уг нурууны нийт талбайн 8,5 \% буюу 80130 га талбайг эзэлнэ. Аж Богдын нурууны 26003000 хүртэл өндөртэй оройн тэгширсэн гадарга, 2000м-ээс доош өндөртэй уулсын хоорондох хөндий хоолойнууд, уулын бэл, хормой орно. Аж Богдын дээд хэсэг нь ихээхэн тэгширсэн нэгэн хэвийн тавцан хэлбэрийн хяртай юм.



Зураг 4: Аж богдын нурууны гадаргын хэвгийн зураг 
$9^{\circ}$ - $15^{\circ}$-ийн налуу гадарга нь Аж Богдын уулт тогтолцооны захын хэсэг, тус нурууны 1800 м-ээс доош өндөртэй гадарга, аараг толгод хамарна. Ийм налуу гадарга 68720 га буюу нийт талбайн $9 \%$ болно.

$15^{\circ}$ - 20은 $и$ н налуу гадарга нь Аж Богдын нурууны 2500-2600 м өндөртэй уулсын хажууг хамарна. Ийм гадарга нийт талбайн 3,8 \% буюу 68720 га талбайг эзэлнэ.

$20^{\circ}-25^{\circ}$-ийн налуу гадарга 2600-3200 м-ийн өндөртэй нутгийг хамарна. Нийт талбайн 2,2 \% буюу 35180 га талбайг эзэлнэ.

$25^{\circ}$ - с дээш налуу гадарга 20460 га талбайтай бөгөөд нийт талбайн 2,2 \%-ийг эзэлнэ. Хажуугийн үйл явц эрчимтэй явагддаг бартаажсан эгц хажуу бүхий 34003600 м-ийн өндөртэй гадарга хамарна.
Хэрчигдлийн шигүу: Аж Богдын нуруу нь өндөр уулсын район тул гадарга, геологийн тогтоцын онцлогоос болоод хамгийн их хэрчигдсэн нутгийн нэгэнд орно.

0-3 км/км2 хүртэл шигүү хэрчигдэлтэй гадарга 346487 га талбайтай бөгөөд нийт талбайн 36,9 \%-ийг эзэлж оршино.

3-6 км/км2 шигүү хэрчигдэлтэй гадарга 309784 га талбайтай бөгөөд нийт талбайн 33,2 \%-ийг эзэлж оршино.

6-9 км/км2 шигүҮ хэрчигдэлтэй гадарга 177008 га талбайтай бөгөөд нийт талбайн 19 \%-ийг эзэлж оршино.

9-12 км/км2 шигүү хэрчигдэлтэй гадарга 86133 га талбайтай бөгөөд нийт талбайн 9,2 \%-ийг эзэлж оршино.

12-15 км/км2 шигүҮ хэрчигдэлтэй гадарга 15388 га талбайтай бөгөөд нийт талбайн 1,7 \%-ийг эзэлж оршино.

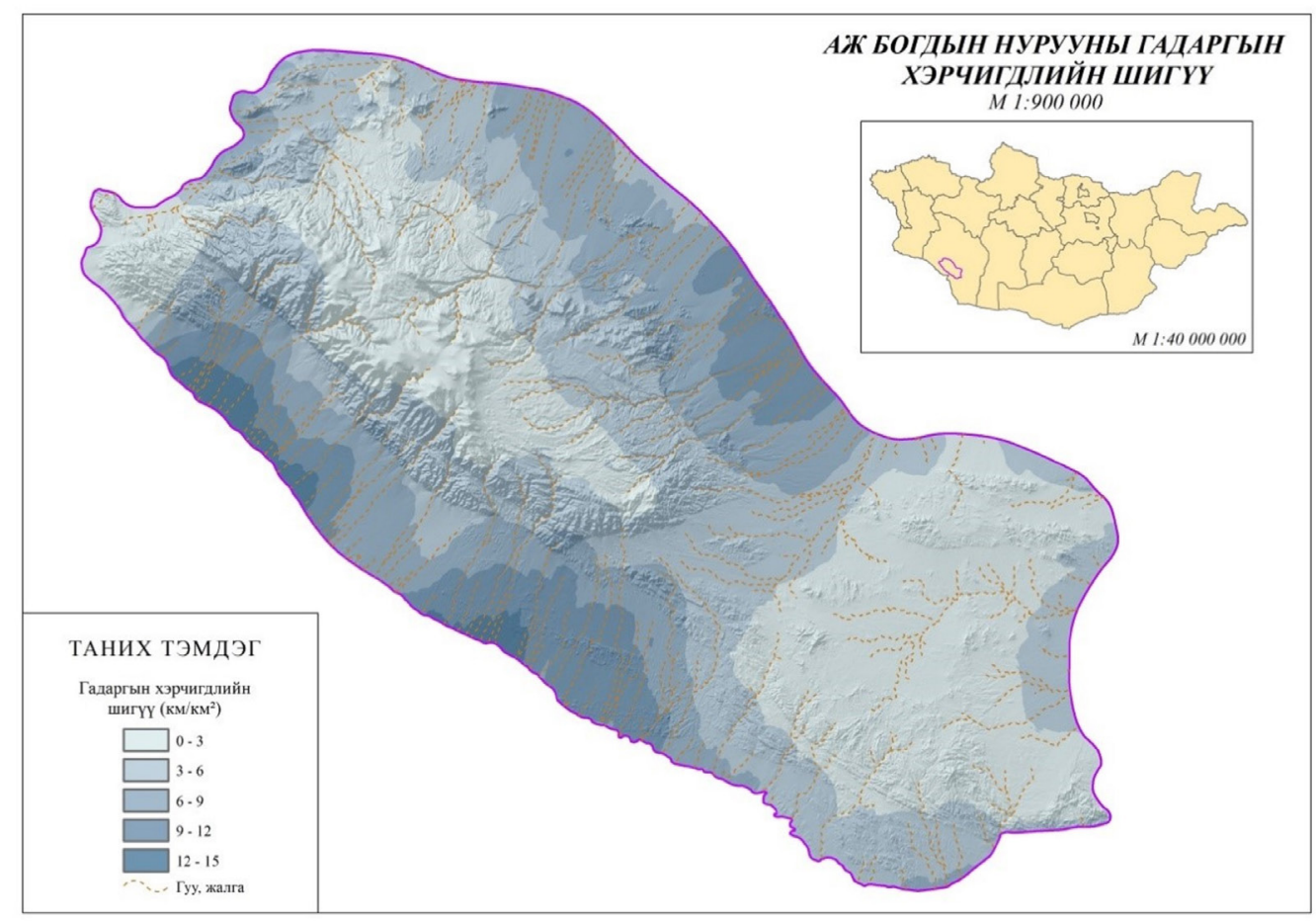

Зураг 5: Аж богдын нурууны гадаргын хэрчигдлийн шигүҮгийн зураг 
Уур амьсгал: Аж Богдын нуруу нь хуурай сэрүүн зунтай, хахир өвөлтэй уур амьсгалын мужид ордог. Алтайн цаг уурын станцын мэдээгээр агаарын температурын хэлбэлзэл 60-70o, хоногийн хэлбэлзэл 2025o-д хүрч жилийн дундаж температур -2 байна. Зун их халуун биш 7-р сарын дундаж температур 160 үнэмлэхүй их температур +29,7 хүрнэ. 1-р сарын дундаж температур -20о үнэмлэхүй хүйтэн -42o хүрдэг байна. Нарны гийгүүлэх хугацаа 2800 цаг, нарны нийлбэр цацраг 1300 кВт/м2, агаарын температурын хоногийн дундаж $+10 \mathrm{o}-\mathrm{aac}$ дээш байх өдрийн тоо 90-аас бага байна. Энд жилд дунджаар 200-250 орчим мм тунадас унадаг. Тунадасны ихэнх нь зуны улирал буюу ид борооны үе 7-р сард унана. Харин өвлийн улиралд цас нилээн их унана. Цасан бүрхүүл бүхий үе 11-р сарын дундаас 20-ноос 4-p сарын 10 хүртэл үргэлжилж тогтвортой цасан бүрхүүл 100 хоног байна. Жилийн ерөнхий үүлшилт 5 баллаас үл хэтэрнэ. Салхины хүч их, жилийн дундаж хурд 3.2 м/сек бол хамгийн их нь 34 м/секээс үл хэтэрнэ [10].

Ус зүй: Аж богдын нурууны өврөөс Идэрийн гол $(17,1 \kappa м)$, Бага гол $(10,8 \kappa м)$, Их гол $(21,1 \kappa м)$, Гишүүнтийн гол $(40,4 \kappa м)$, ap талаас нь Ар зуслангийн гол (36,8км), Баян гол $(50,8 \kappa \mathrm{k})$, Уртын гол $(31,2 \kappa \mathrm{)})$ эх аван урсдаг. Эдгээр цэнгэг устай голуудын олонх нь гол нурууны 3500-3600м өндөртэй намагжсан газар, хярын нуур, булгуудаас эх авч эгц цавчим хавцлуудын дундуур урсана. Аж Богдын нурууны араас эх авсан байнгын урсгалтай эдгээр голууд хур борооны болон цасны усаар тэжээгдэх бөгөөд зуны бороо хаврын шар усны үед үерлэж Төхөмийн хоолой, Тооройн хоолой хотгорт усаа юүлнэ. Аж богдын нурууны өврөөс эх авсан голууд Ажийн тал руу орж шургана. Хуурай сайрууд нь Номингийн говь хүртэл үргэлжилнэ. Өвлийн улиралд мөс тошин үүсгэж голын хөндий хавцлыг дүүргэн мөсөөр хаана. Намар зундаа тогтмол урсан уулынхаа амнуудаас бараг хэтэрч чадахгүй ууршиж голын сайрандаа шингэнэ. Аж
Богдын гол нурууг гүнзгий хавцлуудаар зүсэн гарсан нэвт хөндийтэй гол байхгүй юм. Тус нуруу нь маш гүн хэрчигдсэн, уулсын хажуу маш их налуу, заримдаа бараг эгц хажууг үүсгэсэн байна. Ихэнх төлөв хавцал үүсгэсэн бий. Ерөнхийдөө нарийн хавцлын хэсэг нь үндсэн чулуулаг гадарга дээр гарсан зурвастай холбоотой байна. Голууд нь гол нурууныхаа ноён оргилуудаас эх авна. Хажуу эрс, хадархаг 25 градусаас их хэвгийтэй байна. Харин усны элэгдэл физик өгөршил нэн эрчимтэй явагдсан. Түр зуурын усны урсгал усны үйлчлэлээр сайр олноор үүсч зарим газар шигүҮ оршдогийн улмаас уулын хажуу бэлийг сархиаг болгожээ. Голууд нь цас борооны усаар тэжээгдэх ба тэжээлийн 60$70 \%$ цас, борооны ус байна. Гадаргын усны зэрэгцээ газар доорхи ус элбэг учир гуу, жалга, уулын ам хөндий, хормойгоор булаг шанд болж ундарна. Голуудын хөндий эхэн хэсэгтээ давчуу нарийн, түүний морфологи бүтэц нь V хэлбэрийн зүсэлт үүсгэдэг зүй тогтол энд тодорхой ажиглагдана.

Ландшафт: Аж Богдын нуруунд уулын хээрийн ландшафт хамгийн өргөн дэлгэр хөгжсөн байдаг юм. Уулын хээрийн ландшафтад өндөр уулын хээрийн бүдүүн ялзмагт хөрс голлоно. ...Энэ нуруу Монгол орны ургамал-газар зүйн мужлалтаар Монгол Алтайн нурууг нийтэд нь оруулсан Монгол Алтайн уулт хээрийн районд хамрагдана (В.И.Грубов, 1954)....УГ хөрсний Алтайн уулын системд онцгой ялгаран харагддаг онцлог байдлыг харгалзан бид энэ нутгийг ландшафтын бие даасан дэд хэв шинж болгож уулын хээрийн ландшафтын алтайн дэд хэв шинж гэж ялган үзлээ...[7]

Хөрс: Аж Богдын нуруу хөрс газарзүйн мужлалтаар говийн их мужийн ГовьАлтайн болон Алтайн өвөр говийн дэд мужид өндрийн бүсшилийн алтайн хэвшинжид хамаарна [8]. Уулын хүрэн, цайвар хүрэн, говийн бор, хужир мараат, цөлийн бор саарал хөрстэй. Энэ нуруунд өндөр уулын хээрийн хар хүрэн хөрс 
голлон тархана. Энэ хөрс харьцангуй хүйтэн хуурай нөхцөлд тогтворжих ба нэг талаас чийг нилээд дутагдалтай, нөгөө талаас сүрхий хүйтэн байдаг болохоор хөрс үүсвэрийн үйл явц өвөрмөц шинжтэй.

Ургамал: Аж Богдын нуруугаар алаг өвст-ботуульт, алаг өвс- жижиг дэгнүүлт, үетэн ботуульт уулын хээрийн ургамалшил зонхилно. Аж Богдын нуруунд жимс, жимсгэнээс тошлой, өндөр улаагана (улаалзгана), өргөст нохойн хошуу, үхрийн нүд говьдоо хармаг ургана. Эмийн ургамлаас таван салаа, ягаан мүгэз (алтан гагнуур), согоо суман, эмийн банбай, хошоонгор, цагаан шарилж, морин зээргэнэ, хонин зээргэнэ, алаг цэцэгт башир, үст хөөнгө ортууз, боргоцойрхуу ортууз, эгэл марал цэцэг, говийн ганга, дэгд, үсхий ангалзуур, эгэл өмхий өвс, орогдуу нохойн хэл, марцны хоржигнуур, исэглэн

\section{ДҮГНЭЛТ}

Монгол Алтайн нурууг бүрэлдүүлж байгаа томоохон салбар уулсын нэг Аж Богдын нуруу нь Монгол Алтайн уулт тогтолцооны дунд хэсгийн баруун захаар орших ба Монгол Алтайн гол нуруунаас өмнө тийшээ салбарласан 3 нурууны дунд талын салбар нуруу юм. Аж Богдын нуруу Аж Богдын нуруу нь гадаргын харьцах өндрийн байдал, уул зүйн байрлал, тогтоцын хурган чих ургана. Мөн ашигт ургамлаас хонин арц, гишүүнэ, хурган мэхээр, цагаан мөөг, Алтайн сонгино, ихээхэн тархсан байдаг[2].

Амьтан: Аж Богдын нуруу Монгол орны амьтны газарзүйн мужлалаар Уулархаг Азийн дэд их мужийн Монгол Түвдийн мужийн Баруун хойд Монголын тойрогт хамаарагдана. (А.Г Банников, 1954) Туурайтан аймгийн дотроос аргаль, янгир, хулан, хар сүүлт зээр, махчин амьтдаас ирвэс, хадны суусар, чоно, үнэг, хярс, мануул, шилүүс, өмхий хүрэн, үен түгээмэл тархсан байдаг. Мэрэгч амьтдаас тарвага, зурам, оготно, үхэр огдой, туулай, бор хулгана, шар сүүлт, чичүүл, алаг даахай, жигүүртнээс ятуу, хахилаг, хойлог, ногтруу, тас, бүргэд, ууль, тагтаа, улаан хошуут, ээрүүл шувуу, элээ, бэгбаатар, шаазгай элбэг тохиолдоно.

\section{НОМ ЗУЙ}

1. Мурзаев.Э.М. Монгольская Народная Республика /Физико-географические описание/. Москва.1952. стр 297/.

2. Цэгмид Ш. Монгол орныл физик газарзүй.УБ.1969. /336,364-р хуудас/

3. С.Жигж Монгол орны хотгор гүдгэрийн үндсэн хэв шинж УБ. 1975. / 50,88-p xyydacl

4. Geological map of Mongolia. Scale 1:1.000.000 Ulaanbaatar 1998.

5. Даш Д. Монгол орны ландиафт экологийн зарим асуудлууд. УБ.2000, 93,96-р xуyдас/

6. Тимофеев Д.А, Чичагов В.П. Бэли Монголии. Очерки физической географии Монголии.УБ., 2006

7. Монгол орны ландмафт-экологийн асуудал.УБ.2010 115,127-р хуудас

8. Монгол улсын өрнөд бүс УБ./1999.143-р хуудас/

9. Геолгия МНР, Москва 1973, том I стратиграфия. / стр 20/

10. Говь-Алтай аймгийн уур амьсгал уб.1976 


\title{
PHYSICAL GEOGRAPHIC DEFINITION MOUNTAIN AJ BOGD
}

\author{
E.Avirmed ${ }^{1}$, B.Bayanjargal ${ }^{2}$ \\ Institute of Geography and Geoecology, Mongolian Academy of Sciences \\ E-mail:avirmed_cave@yahoo.com \\ bayanaa_geo@yahoo.com
}

\begin{abstract}
Mountain Aj Bogd is one of branch mountains the mount systems Mongol Altai, which is located at the middle part of Mongol Altai mountain. Mountain Aj Bogd is similar with surface typology, deposits, form relief, erosion and accumulation process, mountain side, dissection, age and landscape of main mountains of Mongol Altai. Aj Bogd Mountain is a mounting system had existed which surrounding by valleys and depressions and related by kotal and pass from the main ridge of the Mongolian Altai mountains.

The Aj Bogd Mountain segregated to the east by Gobi Khonin Us, to the north from the mountain Khubch by pass Zoolin Bogd and the Mongol Altai mountain by depressions of Alag lake, to the west from mountains Ikh Tayan by dale of the Tuhum,Tooroi, to the south by Nomingiin gobi. The highest peak of this mountain Aj Bogd is $3093.3 \mathrm{~m}$ high above the sea level. The relief and peak of a mountain is mostly cupola or plane shaped because of in longest time weathered by wind and water.
\end{abstract}

Keywords: Mountain system, the main ridge, type of surface, land form, mountain side, piedmont, valley, the valley between the mountains, glaciations; 